\title{
Investment-Cash Flow Sensitivity under Financial Constraints Case of Tunisia
}

\author{
Fadoua Marouene ${ }^{1}$ \& Ezzeddine Abaoub $^{2}$ \\ ${ }^{1}$ Graduate School of Business of Tunis, Tunisia \\ ${ }^{2}$ Faculty of Economics and Management of Nabeul, Tunisia \\ Correspondence: Fadoua Marouene, Graduate School of Business of Tunis, Tunisia. E-mail: \\ fadouamarouene@yahoo.com \\ Received: Jaunary 31, 2013 \\ Accepted: February 20, 2013 \\ Online Published: April 14, 2013 \\ doi:10.5539/ijbm.v8n9p14 \\ URL: http://dx.doi.org/10.5539/ijbm.v8n9p14
}

\begin{abstract}
Is investment cash flow sensitivity an adequate measure of a firm's financial constraints? The answer to this question is an unresolved puzzle. This paper theoretically and empirically examines investment cash flow sensitivity and its ability to measure a firm's financial constraints. The empirical study focuses on an unbalanced panel of 88 Tunisian firms observed over the 1997 to 2007 period.
\end{abstract}

Keywords: investment cash flow sensitivity, financial constraints, cost effect, income effect

\section{Introduction}

Earlier theories of financial economics grew more interested in the study of a firm's financial decisions and particularly interdependence of investment and financing decisions. More specifically, Modigliani \& Miller (1958) showed that in a perfect capital market, investment decision is independent of financial considerations; firms can invest without financial constraints and external funds are a perfect substitute for internal funds. However, in a context of imperfect capital markets, external funds are no longer a perfect substitute for internal funds and firms may have financial constraints on their investment decisions.

Financial constraints have been defined differently in the literature. Specifically, Fazzari, Hubbard \& Peterson (1988) argue that a firm is financially constrained if the superiority of the cost of external funds relative to cost of internal funds forces it to forgo profitable projects. In addition, Kaplan \& Zingales (1997) argue that a firm cannot be considered as financially unconstrained if it has significant liquidity that enables it to undertake profitable projects.

Financial constraints have been theoretically and empirically discussed since 1988. Indeed, Fazzari et al. (1988), the pioneers of this literature, have theoretically and empirically shown that financial constraints can be perfectly measured by investment cash flow sensitivity: strong positive sensitivity indicates presence of financial constraints.

This assumption was strongly criticized by Kaplan \& Zingales (1997) who showed that investment cash flow sensitivity can no longer be considered as an adequate measure of financial constraints.

Following these studies, several researchers tried to solve this conflict in results. Among these studies, we mention those of Guariglia (2008) and Cleary, Povel \& Raith (2007) which showed that the results of Fazzari et al. (1988) and Kaplan \& Zingales (1997) do not really diverge but the problem lies in the use of different financial constraints classification criteria. Fazzari et al. (1988) use a classification criterion that correlates with external financial constraints while Kaplan \& Zingales (1997) use a classification criterion that correlates with internal financial constraints.

Guariglia (2008) and Cleary et al. (2007) indicate that the use of classification criteria which correlate with external financial constraints leads to a higher investment cash flow sensitivity for firms that are more financially constrained as a result of cost effect dominance. In contrast, the use of classification criteria which correlate with internal financial constraints may lead to similar or different results, depending on cost effect dominance or income effect.

According to Povel \& Raith (2001) and Cleary et al. (2007), cost effect takes place when the amount of internal 
funds of a firm is not sufficient to finance an optimal level of investment. In this case, a decrease in internal funds leads to a decrease in investment.

However, income effect arises when internal funds of a firm are very low or negative. Firms increase their investment in the event of a further decrease in internal funds.

Indeed, firms with low internal funds tend to invest less, but at the same time they have a strong need for external funds and then face a high bankruptcy risk. For this type of firms, increasing investment improves their ability to repay debts and generates an increase in their income and therefore reduces bankruptcy risk. These companies accept the additional cost of external funds and increase their investment to reach their optimum investment level. Therefore, below a certain level of internal funds, a decrease in these funds will lead to an increase in investment: the income effect dominates the cost effect as well.

In this paper, we theoretically and empirically examine investment cash flow sensitivity and its ability to measure a firm's financial constraints while testing the cost and income effects.

The remainder of this paper is structured as follows. In Section 2, we review the instruments we used to measure internal and external financial constraints. In Section 3, we present our sample. In Section 4, we describe our criteria for classifying the firms of our sample. In Section 5, we present our methodology. In Section 6, we present the results of our estimates. Section 7 concludes.

\section{Measuring Financial Constraints}

We distinguish between external financial constraints and internal financial constraints.

External financial constraints relate to information asymmetry problems which reflect difficulty in obtaining external funds.

Internal financial constraints relate to level of internal funds generated by and available to the firm.

\subsection{Measures of External Financial Constraints}

External financial constraints reflect the degree of difficulty in obtaining external funds. We thus consider the retention ratio, size, listing, age, membership to a group of companies and bond ratings as criteria for measuring external financial constraints.

\subsubsection{Retention Ratio and Financial Constraints}

A large literature has highlighted the fact that high-retention firms are more financially constrained than low-retention firms (Fazzari et al., 1988; Cleary, 1999; Hovakimian, \& Titman, 2006; Chang Tan, Wong \& Zhang, 2007; Guariglia, 2008 \& Bushman; Smith \& Zhang, 2012).

According to Fazzari et al. (1988), failure of a firm to pay dividends is due either to a need for financing investments in excess of its available cash flow or to a lack of funds to operate. Guariglia (2008) considers payment of dividends as a signal of the potential prospects of a firm. Firms that pay high dividends indicate their good long-term prospects. Obtaining external funding will make it easier and less costly for low-retention firms unlike high-retention firms.

\subsubsection{Size and Financial Constraints}

Several studies have considered size as a measure of financial constraints (Guariglia, 2008; Chang et al., 2007; Gilchrist, \& Himmelberg, 1995; Gertler \& Gilchrest, 1994; Himmelberg \& Peterson, 1994; Oliner \& Rudebusch, 1992).

Hovakimian \& Titman (2006) propose three reasons why size is one of the most relevant measures of financial constraints:

1) The empirical results indicate that transaction costs decrease with size, which makes external funds relatively more expensive for small firms.

2) Small firms may have more limited access to external financing because of adverse selection problems.

3) Large firms can more easily increase their debt because they are more diversified and have less bankruptcy risk.

\subsubsection{Listing and Financial Constraints}

We consider listing as a classification criterion of firms in terms of their degree of external financial constraints. Intuitively, listed companies are less financially constrained than unlisted companies, for at least two reasons. The first is that listed companies have less problems of information asymmetry that unlisted companies because 
they must report regularly on the stock market. The second is that these companies are usually large and have easy access to capital markets, which is not the case of unlisted companies which are generally small and constrained to enter external markets.

Guariglia (2008) supports this idea by assuming that financial constraints of listed firms are probably less severe, since these firms are typically large, older, have a sound financial position and a good bond rating.

However, unlisted firms are generally characterized by a lower solvency, a shorter professional experience and lower total assets than listed firms.

\subsubsection{Age and Financial Constraints}

Several theoretical and empirical studies have assumed that age is a good indicator of financial constraints of firms (Guariglia, 2008; Beck et al., 2004; Oliner \& Rudebusch, 1992: Devreux, \& Schiantarelli, 1990; Gertler, 1988).

Indeed, young firms have quite important information asymmetry problems because they are relatively unknown. Therefore, the cost of external financing for these firms presents a risk premium making it more expensive than for mature firms.

\subsubsection{Membership to a Group of Companies and Financial Constraints}

Belonging to a group of companies can be considered as a criterion to measure financial constraints. Indeed, firms belonging to a group of companies may have easier access to capital markets than independent firms. Part of the literature has examined investment sensitivity to cash flow depending on whether or not the firm belongs to a group of companies. Of these, we can mention Hoshi, Kashyap \& Scharfstein (1991) and Kato, Loewenstein \& Tsay (2002) for Japanese firms, Shin \& Park (1999) for Korean firms and George, Kabir \& Qian (2011) for Indian companies.

\subsubsection{Bond Rating and Financial Constraints}

Guariglia (2008), Hovakimian \& Titman (2006), Gilchrist \& Himmelberg (1995), Kashyap et al. (1994) and Whited (1992) argue that bond rating is a measure of external financial constraints. Firms with a bond rating are usually large, mature and have easy access to capital markets.

\subsection{Measurement of Internal Financial Constraints}

Internal financial constraints are those related to the level of internal funds generated by and available to the firm. We thus consider cash flow and $Z_{\mathrm{FC}}$ score as criteria to measure external financial constraints.

\subsubsection{Cash Flow and Financial Constraints}

Cash flow has been widely used in the literature as a criterion for measuring internal funds (Guariglia, 2008; Cleary et al., 2007 and Hubbard, 1998).

Indeed, cash flow is the main source of variation of internal funds and firms with negative cash flow have probably low or negative levels of internal funds that are considered in financial distress.

\subsection{2 $\mathrm{Z}_{\mathrm{FC}}$ Score and Financial Constraints}

Cleary $(1999,2000)$ and Chang et al. (2007) use a number of variables that highly correlate with firms' internal funds (current and reduced cash flow ratio, coverage ratio, debt ratio, etc.) to construct an index of financial strength, called score. This score is determined from a multiple discriminant analysis using a series of variables specific to firms and establishes a feature that better distinguishes financially constrained firms from financially unconstrained firms.

\section{Sample}

Our empirical study focuses on an unbalanced panel composed of 88 Tunisian firms observed over the 1997 to 2007 period.

\section{Classification of Firms}

We classify firms according to criterion of measuring external financial constraints, the most commonly used in the literature, namely retention ratio and according to two measures of internal financial constraints, namely cash flow (to distinguish firms in financial distress) and the $\mathrm{Z}_{\mathrm{FC}}$ score.

\subsection{Retention Ratio-Based Classification}

We divide our sample into two classes according to the retention ratio. The high-retention class of firms includes companies with an average retention ratio greater than 0.90 . The low-retention class of firms combines the 
remaining firms. According to this classification, our sample is divided into 53 high-retention firms and 35 low-retention firms.

\subsection{Cash Flow-Based Classification}

We adopt the same classification criteria used by Guariglia (2008), namely cash flow divided by capital stock. We classify the sample into three subgroups: negative cash flow, low cash flow and high cash flow. The subgroup "negative cash flow" includes firms with an average negative cash flow. The subgroup "low cash flow" includes firms with a non-negative average cash flow inferior to the 75th percentile of the sample distribution.

The subgroup "high cash flow" includes firms with an average cash flow superior to the 75th percentile of the sample distribution. We totalled 15 firms with negative cash flow, 54 firms with low cash flow and 19 firms with high cash flow.

\subsection{1 $\mathrm{Z}_{\mathrm{FC}}$ Score-Based Classification}

We adopt the $Z_{\mathrm{FC}}$ score of Chang et al. (2007) as follows:

$$
Z_{F C}=0.2398 \times R L G-0.0193 \times R C F F+0.7519 \times R L R+7.7615 \times M N+0.7519 \times V E N T E S-4.112 \times L E V I E R
$$

This score uses the same variables as Kaplan \& Zingales (1997). These ratios are the current cash flow ratio(RLG) and the reduced cash flow ratio (RLR) to control liquidity, debt ratios (LEVIER) and cost covering ratio (RCFF) to capture leverage effect, net margin ratio (MN) to measure profitability and sales growth (SALES) is used as a proxy for growth potential.

We consider a financially constrained firm if its average $Z_{\mathrm{FC}}$ score is below the 25 th percentile of the sample distribution, probably financially constrained if its average $\mathrm{Z}_{\mathrm{FC}}$ score is between the 25 th and 75 th percentile and financially unconstrained if its $Z_{\mathrm{FC}}$ score is superior to the 75th percentile of the sample distribution.

We totalled 23 financially-constrained firms, 40 probably financially-constrained firms and 25 financially-unconstrained firms.

\section{Methodology}

To study investment sensitivity to cash flow, first of all we choose the to-be estimated investment models. Then, we define the variables of the models and finally we set the estimation method.

\subsection{The To-Be-Estimated Investment Models}

The models that we consider are dynamic models proposed by Bond, Elston, Mairesse \& Mulkey (2003). These are the accelerator model and the error correction model.

According to the accelerator model, the regression to be estimated is as follows:

$$
\left(I_{i, t} / K_{i, t-1}\right)=\alpha_{0}+\alpha_{1}\left(I_{i, t} / K_{i, t-2}\right)+\alpha_{2} \Delta y_{i, t}+\alpha_{3} \Delta y_{i, t-1}+\alpha_{4}\left(C F_{i, t} / K_{i, t-1}\right)+\varepsilon_{i, t}
$$

According to the error correction model, the regression to be estimated is as follows:

$$
\left(I_{i, t} / K_{i, t-1}\right)=\alpha_{0}+\alpha_{1}\left(I_{i, t} / K_{i, t-2}\right)+\alpha_{2} \Delta y_{i, t}+\alpha_{3} \Delta y_{i, t-1}+\alpha_{4}\left(C F_{i, t} / K_{i, t-1}\right)+\alpha_{5}\left(K_{i, t-2}-y_{i, t-2}\right)+\varepsilon_{i, t}
$$

$I_{i, t}$ is the investment of firm $\mathrm{i}$ at year $\mathrm{t}$.

$K_{i, t}$ is the capital stock of firm $i$ at year $\mathrm{t}$.

$y_{i, t}$ is the sales logarithm of firm $i$ at year $t$.

$C F_{i, t}$ is the cash flow of firm i at year $\mathrm{t}$.

$K_{i, t}$ is the capital stock logarithm of firm $i$ at year t.

$\varepsilon_{i, t}$ is error term.

To test the investment sensitivity to cash flow according to degree of financial constraints, we incorporate in the to be estimated investment models cash flow interactive variables with a dummy variable referring to the class of firms.

The models to be estimated thus become:

The accelerator model:

$$
\left(I_{i, t} / K_{i, t-1}\right)=\alpha_{0}+\alpha_{1}\left(I_{i, t} / K_{i, t-2}\right)+\alpha_{2} \Delta y_{i, t}+\alpha_{3} \Delta y_{i, t-1}+\alpha_{4}\left(C F_{i, t} / K_{i, t-1} \times C L A S S_{j}\right)+\varepsilon_{i, t}
$$

The error correction model 


$$
\left(I_{i, t} / K_{i, t-1}\right)=\alpha_{0}+\alpha_{1}\left(I_{i, t} / K_{i, t-2}\right)+\alpha_{2} \Delta y_{i, t}+\alpha_{3} \Delta y_{i, t-1}+\alpha_{4, j}\left(C F_{i, t} / K_{i, t-1} \times C L A S S\right)+\alpha_{5}\left(K_{i, t-2}-y_{i, t-2}\right)+\varepsilon_{i, t}
$$

Where CLASS $\mathrm{j}$ is a dummy variable which takes the value 1 or 0 according to whether the firm belongs or not to a given class of firms.

\subsection{Estimation Method}

We adopt the Generalized Method of Moments (GMM) for the estimation of panel data dynamic models of Blundell \& Bond (1998).

\section{Estimation Results}

After confirming the absence of multicolinearity problem for the independent variables (see Table 1), we proceed to estimate the accelerator and error correction models for the entire sample and for the different classes of firms.

Table 1. Multicolinearity between independent variables

\begin{tabular}{cccccc}
\hline & $I_{i, t-1} / K_{i, t-2}$ & $C F_{i, t} / K_{i, t-1}$ & $\Delta y_{i, t}$ & $\Delta y_{i, t-1}$ & $K_{i, t-2}-y_{i, t-2}$ \\
\hline$I_{i, t-1} / K_{i, t-2}$ & 1.0000 & & & & \\
$C F_{i, t} / K_{i, t-1}$ & 0.0405 & 1.0000 & & & \\
$\Delta y_{i, t}$ & 0.1764 & 0.1884 & 1.0000 & & \\
$\Delta y_{i, t-1}$ & -0.0134 & 0.0996 & -0.0611 & 1.0000 & \\
$K_{i, t-2}-y_{i, t-2}$ & -0.0596 & -0.2430 & 0.0036 & 0.1905 & 1.0000 \\
$1 / \mathrm{VIF}$ & 0.979683 & 0.844683 & 0.918810 & 0.931872 & 0.873445 \\
\hline
\end{tabular}

\subsection{Investment Cash Flow Sensitivity for the Entire Sample}

The results of estimating the accelerator and error correction models without interactive variables are reported in Table 2.

Table 2. Investment cash flow sensitivity for the entire sample

\begin{tabular}{ccc}
\hline $\begin{array}{c}\text { Dependent variable } \\
I_{i, t-1} / K_{i, t-1}\end{array}$ & Accelerator & Error correction \\
\hline Constant & -0.024 & -0.029 \\
& $(-0.73)$ & $(-0.94)$ \\
$I_{i, t-1} / K_{i, t-2}$ & -0.010 & 0.067 \\
$\Delta y_{i, t}$ & $(-0.18)$ & $(0.58)$ \\
$\Delta y_{i, t-1}$ & $-0.180^{* * *}$ & 0.124 \\
$C F_{i, t} / K_{i, t-1}$ & $(-3.15)$ & $(1.03)$ \\
$K_{i, t-2}-y_{i, t-2}$ & -0.059 & 0.013 \\
& $(-1.50)$ & $(0.13)$ \\
Sargan/Hansen & $0.121^{* *}$ & $0.186^{* * *}$ \\
& $(2.53)$ & $(3.30)$ \\
$m_{2}$ & & 0.038 \\
& & $(1.43)$ \\
Number of observations & 17.63 & 15.76 \\
& {$[0.480]$} & {$[0.470]$} \\
& -0.42 & -0.52 \\
& {$[0.677]$} & {$[0.606]$} \\
\hline
\end{tabular}

*** Significant at $1 \%$, ** significant at $5 \%$, significant at $10 \%$.

The values ( ) are $z$ statistics.

The values [ ] are critical probabilities of the Sargan/Hansen tests and order 2 autocorrelation. 
Both accelerators and error correction models generate the same results on investment cash flow sensitivity, i.e. the coefficient for the variable cash flow is significantly positive implying that investment of Tunisian firms is significantly sensitive to cash flow.

\subsection{Investment Cash Flow Sensitivity and Retention Ratio-Based Classification}

To test investment cash flow sensitivity for firms classified according to the retention ratio, we estimate the following regressions:

The Accelerator model:

$$
\left(I_{i, t} / K_{i, t-1}\right)=\alpha_{0}+\alpha_{1}\left(I_{i, t} / K_{i, t-2}\right)+\alpha_{2} \Delta y_{i, t}+\alpha_{3} \Delta y_{i, t-1}+\alpha_{4}\left(C F_{i, t} / K_{i, t-1} \times H R\right)+\alpha_{5}\left(C F_{i, t} / K_{i, t-1} \times L R\right)+\varepsilon_{i, t}
$$

The Error correction model:

$$
\left(I_{i, t} / K_{i, t-1}\right)=\alpha_{0}+\alpha_{1}\left(I_{i, t} / K_{i, t-2}\right)+\alpha_{2} \Delta y_{i, t}+\alpha_{3} \Delta y_{i, t-1}+\alpha_{4}\left(C F_{i, t} / K_{i, t-1} \times H R+\alpha_{5}\left(C F_{i, t} / K_{i, t-1} \times L R\right)+\alpha_{6}\left(K_{i, t-2}-y_{i, t-2}\right)+\varepsilon_{i, t}\right.
$$

Where:

HR is a dummy variable which takes the value of 1 if the firm is a high-retention firm, otherwise 0 .

LR is a dummy variable which takes the value of 1 if the firm is a low-retention firm, otherwise 0 .

The results of the estimations are reported in Table 3.

Table 3. Investment cash flow sensitivity: retention ratio-based classification

\begin{tabular}{ccc}
\hline Dependent variable & Accelerator & Error correction \\
$I_{i, t-1} / K_{i, t-1}$ & $-0.071^{*}$ & 0.089 \\
Constant & $(-1.90)$ & $(0.50)$ \\
$I_{i, t-1} / K_{i, t-2}$ & -0.038 & -0.125 \\
& $(-0.29)$ & $(-0.491)$ \\
$\Delta y_{i, t}$ & $0.371^{*}$ & -0.152 \\
& $(1.81)$ & $(-0.53)$ \\
$\Delta y_{i, t-1}$ & 0.061 & -0.153 \\
$C F_{i, t} / K_{i, t-1} \times H R$ & $(0.43)$ & $(-0.82)$ \\
$C F_{i, t} / K_{i, t-1} \times L R$ & $0.314^{* * *}$ & $0.620^{* * *}$ \\
$K_{i, t-2}-y_{i, t-2}$ & $(2.81)$ & $(3.13)$ \\
Sargan/Hansen & $0.106^{*}$ & $0.219^{*}$ \\
& $(1.74)$ & $(1.73)$ \\
$\mathrm{m}_{2}$ & & 0.203 \\
& & $(1.40)$ \\
Number of observations & 19.87 & 9.19 \\
& {$[0.177]$} & {$[0.818]$} \\
\end{tabular}

*** Significant at $1 \%$, ** significant at $5 \%$, significant at $10 \%$.

The values ( ) are $\mathrm{z}$ statistics.

The values [ ] are critical probabilities of the Sargan/Hansen tests and order 2 autocorrelation.

The coefficient of the interactive variable is significantly higher for firms with high retention considered as the most financially constrained firms. Thus, we replicate the results of Fazzari et al. (1988) which indicate that investment cash flow sensitivity is higher for highly financially constrained firms. Similarly, this result is consistent with the results of Guariglia (2008) and Cleary et al. (2007) according to which classification of firms according to a criterion of external financial constraints leads to cost effect dominance and therefore a greater sensitivity of the highly financially constrained firms.

\subsection{Investment Cash Flow Sensitivity and Cash Flow-Based Classification}

We test investment cash flow sensitivity for the three classes of firms: negative cash flow, average cash flow 
and high cash flow, incorporating the basic models of cash flow interactive variables with the different classes. We thus obtain the following to-be-estimated models:

The accelerator model:

$$
\begin{aligned}
\left(I_{i, t} / K_{i, t-1}\right)=\alpha_{0}+\alpha_{1}\left(I_{i, t-1} / K_{i, t-2}\right)+ & \alpha_{2} \Delta y_{i, t}+\alpha_{3} \Delta y_{i, t-1}+\alpha_{4}\left(C F_{i, t} / K_{i, t-1} \times N C F\right)+\alpha_{5}\left(C F_{i, t} / K_{i, t-1} \times L C F\right) \\
& +\alpha_{6}\left(C F_{i, t} / K_{i, t-1} \times H C F\right)+\varepsilon_{i, t}
\end{aligned}
$$

The Error correction model:

$$
\begin{gathered}
\left(I_{i, t} / K_{i, t-1}\right)=\alpha_{0}+\alpha_{1}\left(I_{i, t-1} / K_{i, t-2}\right)+\alpha_{2} \Delta y_{i, t}+\alpha_{3} \Delta y_{i, t-1}+\alpha_{4}\left(C F_{i, t} / K_{i, t-1} \times N C F\right)+\alpha_{5}\left(C F_{i, t} / K_{i, t-1} \times L C F\right) \\
+\alpha_{6}\left(C F_{i, t} / K_{i, t-1} \times H C F\right)+\alpha_{6}\left(K_{i, t-2}-y_{i, t-2} \times H C F\right)+\varepsilon_{i, t}
\end{gathered}
$$

NCF is a dummy variable that takes the value 1 if the firm is a negative cash flow firm, otherwise 0 . LCF is a dummy variable that takes the value 1 if the firm is classified into the low cash flow subgroup of firms, otherwise 0 . HCF is a dummy variable that takes the value 1 if the firm is classified into the high cash flow subgroup of firms, otherwise 0 .

The estimation results are presented in Table 4.

Table 4. Investment cash flow sensitivity: cash flow-based classification

\begin{tabular}{ccc}
\hline $\begin{array}{c}\text { Dependent variable } \\
I_{i, t-1} / K_{i, t-1}\end{array}$ & Accelerator & Error correction \\
\hline Constant & $-0.178^{* *}$ & -0.103 \\
& $(-2.19)$ & $(-0.52)$ \\
$I_{i, t-1} / K_{i, t-2}$ & -0.040 & -0.09 \\
$\Delta y_{i, t}$ & $(-0.29)$ & $(-0.64)$ \\
$\Delta y_{i, t-1}$ & $-0.503^{* *}$ & -0.262 \\
& $(-2.22)$ & $(-1.04)$ \\
$C F_{i, t} / K_{i, t-1} \times N C F$ & -0.059 & -0.159 \\
$C F_{i, t} / K_{i, t-1} \times L C F$ & $(-0.36)$ & $(-1.11)$ \\
$C F_{i, t} / K_{i, t-1} \times R C F$ & $-0.338^{* *}$ & $-0.312^{*}$ \\
$K_{i, t-2}-y_{i, t-2}$ & $(1.99)$ & $(-1.67)$ \\
Sargan/Hansen & $0.393^{*}$ & 0.578 \\
& $(1.67)$ & $(1.50)$ \\
$\mathrm{m}_{2}$ & $0.262^{* * *}$ & $0.324^{* * *}$ \\
& $(3.49)$ & $(3.10)$ \\
Number of observations & & 0.056 \\
& & $(0.55)$ \\
\end{tabular}

*** Significant at $1 \%, * *$ significant at $5 \%, *$ significant at $10 \%$.

The values ( ) are $\mathrm{z}$ statistics.

The values [ ] are critical probabilities of the Sargan/Hansen tests and order 2 autocorrelation.

The results indicate that for negative cash flow firms, the coefficient of the interactive variable is significantly negative, showing income effect dominance for this class of firms. This result is consistent with the studies of Guariglia (2008), Cleary et al. (2007) and Chang et al. (2007).

For the other two classes of firms, the results point to a cost effect dominance with a positive and highly significant sensitivity for high cash flow firms. Average cash flow firms show a less significant sensitivity, but the coefficient of the interactive variable for this class of firms is higher than that for high cash flow firms.

6.4 Investment Cash Flow Sensitivity and $\mathrm{Z}_{F C}$ Score-Based Classification

We check for the dominance of the cost effect by another classification criterion of the degree of internal 
financial constraints, namely the $Z_{\mathrm{FC}}$ score. To control for the income effect on negative cash flow firms, we eliminate these firms from the sample.

We estimate the following two models:

The Accelerator model:

$$
\begin{aligned}
\left(I_{i, t} / K_{i, t-1}\right)=\alpha_{0}+\alpha_{1}\left(I_{i, t-1} / K_{i, t-2}\right)+ & \alpha_{2} \Delta y_{i, t}+\alpha_{3} \Delta y_{i, t-1}+\alpha_{4}\left(C F_{i, t} / K_{i, t-1} \times F C\right)+\alpha_{5}\left(C F_{i, t} / K_{i, t-1} \times P F C\right) \\
& +\alpha_{6}\left(C F_{i, t} / K_{i, t-1} \times N F C\right)+\varepsilon_{i, t}
\end{aligned}
$$

The Error correction model:

$$
\begin{gathered}
\left(I_{i, t} / K_{i, t-1}\right)=\alpha_{0}+\alpha_{1}\left(I_{i, t-1} / K_{i, t-2}\right)+\alpha_{2} \Delta y_{i, t}+\alpha_{3} \Delta y_{i, t-1}+\alpha_{4}\left(C F_{i, t} / K_{i, t-1} \times F C\right)+\alpha_{5}\left(C F_{i, t} / K_{i, t-1} \times P F C\right) \\
+\alpha_{6}\left(C F_{i, t} / K_{i, t-1} \times N F C\right)+\alpha_{7}\left(K_{i, t-1}-y_{i, t-2}\right)+\varepsilon_{i, t}
\end{gathered}
$$

FC is a dummy variable that takes the value 1 if the firm is considered financially constrained according to the $\mathrm{Z}_{\mathrm{FC}}$ criterion, otherwise 0 . PFC is a dummy variable that takes the value 1 if the firm is considered probably financially constrained according to the $Z_{\mathrm{FC}}$ criterion, otherwise 0 . NFC is a dummy variable that takes the value 1 if the firm is considered financially unconstrained according to the $Z_{\mathrm{FC}}$ criterion, otherwise 0 .

The results of the estimations are reported in table 5 .

Table 5. Investment cash flow sensitivity: $\mathrm{Z}_{\mathrm{FC}}$ score-based classification after eliminating negative cash flow observations

\begin{tabular}{ccc}
\hline $\begin{array}{c}\text { Dependent variable } \\
I_{i, t-1} / K_{i, t-1}\end{array}$ & Accelerator & Error correction \\
\hline Constant & $-0.154^{* * *}$ & $-0.297^{*}$ \\
& $(-3.06)$ & $(-1.92)$ \\
$I_{i, t-1} / K_{i, t-2}$ & -0.171 & -0.105 \\
$\Delta y_{i, t}$ & $(-1.48)$ & $(-0.82)$ \\
$\Delta y_{i, t-1}$ & $-0.508^{* *}$ & 0.071 \\
& $(-2.26)$ & $(0.22)$ \\
$C F_{i, t} / K_{i, t-1} \times F C$ & 0.010 & 0.314 \\
$C F_{i, t} / K_{i, t-1} \times P F C$ & $(0.08)$ & $(1.60)$ \\
$C F_{i, t} / K_{i, t-1} \times N F C$ & $0.337^{* *}$ & $0.568^{* * *}$ \\
$K_{i, t-2}-y_{i, t-2}$ & $(2.35)$ & $(3.14)$ \\
Sargan/Hansen & $0.230^{* * *}$ & $0.406^{* * *}$ \\
& $(2.68)$ & $(2.74)$ \\
$\mathrm{m}_{2}$ & $0.230^{*}$ & $0.288^{*}$ \\
& $(1.83)$ & $(1.67)$ \\
Number of observations & & 0.015 \\
& & $(0.14)$ \\
\end{tabular}

*** Significant at $1 \%, * *$ significant at $5 \%, *$ significant at $10 \%$.

The values ( ) are z statistics.

The values [ ] are critical probabilities of the Sargan/Hansen tests and order 2 autocorrelation.

The most important coefficient of the interactive variable is for companies belonging to the class of financially constrained firms, next comes the class of probably financially constrained firms and last the financially unconstrained firms. These latter have the lowest and the least significant coefficient. This result further confirms the cost effect dominance and supports the results of Fazzari et al. (1988) and contradicts those of Kaplan \& Zingales (1997) and Cleary (1999). 


\section{Conclusion}

Investment cash flow sensitivity and its ability to measure financial constraints of firms has been subject of a theoretical and empirical debate for several years, since 1988 until today.

Fazzari et al. (1988) have theoretically and empirically shown that financial constraints can be perfectly measured by investment cash flow sensitivity: a strong positive sensitivity indicates the existence of financial constraints.

In contrast, Kaplan \& Zingales (1997) contradicted the results of Fazzari et al. (1988) showing that investment cash flow sensitivity can no longer be considered as an adequate measure of financial constraints of firms.

Several researchers have attempted to resolve this discrepancy in results. We mainly mention the studies of Guariglia (2008) and Cleary et al. (2007) which indicated that the results of Fazzari et al. (1988) and Kaplan \& Zingales (1997) are not really inconsistent but the problem lies in the use of different classification criteria of financial constraints.

Guariglia (2008) and Cleary et al. (2007) assumed that the use of classification criteria that correlate with external financial constraints leads to a higher sensitivity of investment to cash flow for highly financially constrained firms as a result of the cost effect dominance. However, the use of classification criteria that correlate with internal financial constraints may lead to similar or divergent results according to either the cost effect or the income effect is dominating.

In this paper, we examined investment cash flow sensitivity in the Tunisian context by classifying firms according to a criterion of internal financial constraints, i.e. retention ratio, in addition to two other criteria of external financial constraints, i.e. cash flow and the $\mathrm{Z}_{\mathrm{FC}}$ score.

We firstly tested investment cash flow sensitivity for the entire sample and found that sensitivity was significantly positive.

We then classified firms according to the retention ratio. We found that investment cash flow sensitivity is more important for highly financially constrained firms. This result shows the dominance of the cost effect and agrees with the results of Fazzari et al. (1988), on the one hand, and Guariglia (2008) and Cleary et al. (2007) on the other.

Finally, we classified firms according to the criteria of internal financial constraints (cash flow and the $Z_{\mathrm{FC}}$ score) and concluded that:

-For firms with negative cash flow supposed to be in financial distress, investment cash flow sensitivity was negative, indicating dominance of the income effect for this class of firms and confirming the results of Guariglia (2008) and Cleary et al. (2007).

-For the remaining firms, investment cash flow sensitivity is more important for highly financially constrained firms. This result confirms once more the results of Fazzari et al. (1988) and shows dominance of the cost effect and not the income effect.

For our Tunisian sample, we conclude that whatever the classification criteria adopted cost effect dominates income effect and that greater investment cash flow sensitivity implies more severe financial constraints.

\section{References}

Beck, T., Demirgüç, K. A., Laeven, L., \& Maksimovic, V. (2006). The determinants of financing obstacles.

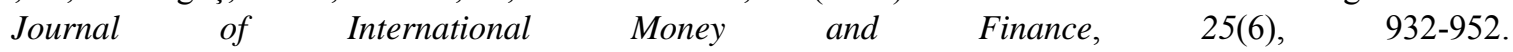
http://dx.doi.org/10.1016/j.jimonfin.2006.07.005

Bond, S., Elston, J., Mairesse, J., \& Mulkey, B. (2003). Financial factors and investment in Belgium, France, Germany and the UK: a comparison using company panel data. The Review of Economics and Statistics, 85(1), 153-165. http://dx.doi.org/10.1162/003465303762687776

Chang, X., Tan, T. J., Wong, G., \& Zhang, H. (2007). Effects of financial constraints on corporate policies in Australia. Accounting and Finance, 47, 85-108. http://dx.doi.org/10.1111/j.1467-629X.2007.00200.x

Cleary, S. (1999). The relationship between firm investment and financial status. Journal of Finance, 54(2), 673-692. http://dx.doi.org/10.1111/0022-1082.00121

Cleary, S. (2000). The sensitivity of Canadian corporate investment to liquidity. Canadian Journal of Administrative Sciences, 17(3), 217-232. http://dx.doi.org/10.1111/j.1936-4490.2000.tb00222.x

Cleary, S., Povel, P., \& Raith, M. (2007). The U-shaped investment curve: Theory and evidence. Journal of 
Financial and Quantitative Analysis, 40, 1-40. http://dx.doi.org/10.1017/S0022109000002179

Fazzari, S. M., Hubbard, R. G., \& Peterson, B. C. (1988). Financing constraints and corporate investment. Brooking Papers on Economic Activity, 1, 141-195. http://dx.doi.org/10.2307/2534426

George, R., Kabir, R., \& Qian, J. (2011). Investment-Cash Flow Sensitivity and Financing Constraints: New Evidence from Indian Business Group Firms. Journal of Multinational Financial Management, 21(2). http://dx.doi.org/10.1016/j.mulfin.2010.12.003

Gertler, M. (1988). Financial structure and aggregate economic activity: an overview. Journal of Money, Credit and Banking, 20, 559-596. http://dx.doi.org/10.2307/1992535

Gertler, M., \& Gilchrist, S. (1994). Monetary policy, business cycles, and the behavior of small manufacturing firms. Quarterly Journal of Economics, 109, 309-340. http://dx.doi.org/10.2307/2118465

Gilchrist, S., \& Himmelberg, C. P. (1995). Evidence on the role of cash flow for investment. Journal of Monetary Economics, 36, 541-572. http://dx.doi.org/10.1016/0304-3932(95)01223-0

Guariglia, A. (2008). Internal financial constraints, external financial constraints, and investment choice: evidence from a panel of UK firms. Journal of Banking \& Finance, 32, 1795-1809. http://dx.doi.org/10.1016/j.jbankfin.2007.12.008

Himmelberg, C. P., \& Peterson, B. (1994). R \& D and internal finance: a panel study of small firms in high tech industries. Review of Economics and Statistics, 76, 38-51. http://dx.doi.org/10.2307/2109824

Hoshi, T., Kashyap, A., \& Scharfstein, D. (1991). Corporate structure, liquidity and investment: evidence from Japanese groups. Quarterly Journal of Economics, 56, 33-60. http://dx.doi.org/10.2307/2937905

Hovakimian, G., \& Titman, S. (2006). Corporate investment with financial constraints: sensitivity of investment to funds from voluntary asset sales. Journal of Money Credit and Banking, 38, 357-374. http://dx.doi.org/10.1353/mcb.2006.0034

Hubbard, R. G. (1998). Capital-market imperfections and investment. Journal of Economic Literature, 36, 193-225.

Kaplan, S. N., \& Zingales, L. (1997). Do investment-cash flow sensitivities provide useful measures of financing constraints? Quarterly Journal of Economics, 112, 169-215. http://dx.doi.org/10.1162/003355397555163

Kashyap, A., Lamont, O., \& Stein, J. (1994). Credit conditions and the cyclical behavior of inventories. Quarterly Journal of Economics, 109, 565-592. http://dx.doi.org/10.2307/2118414

Kato, H., Loewenstein, U., \& Tsay, W. (2002). Dividend policy, cash flow, and investment in Japan. Pacific-Basin Finance Journal, 10, 443-473. http://dx.doi.org/10.1016/S0927-538X(02)00068-9

Modigliani, F., \& Miller, M. (1958). The cost of capital, corporation finance and the theory of investment. American Economic Review, 48, 261-297.

Oliner, S. D., \& Rudebusch, G. D. (1992). Sources of financing hierarchy for business investment. The Review of Economics and Statistics, 74(4), 643-654. http://dx.doi.org/10.2307/2109378

Shin, H. H., \& Park, Y. (1999). Financing constraints and internal capital markets: evidence from Korean 'Chaebols'. Journal of Corporate Finance, 5, 169-191. http://dx.doi.org/10.1016/S0929-1199(99)00002-4

Whited, T. M. (1992). Debt, liquidity, constraints, and corporate investment: evidence from panel data. Journal of Finance, 47, 1425-1470. http://dx.doi.org/10.1111/j.1540-6261.1992.tb04664.x 